\title{
Pemberdayaan Masyarakat Desa Karangsong dalam Pemanfaatan Ikan Non Ekonomi dan Limbah Kulit Udang
}

\author{
Idah Hamidah ${ }^{1}$, Lesy Luzyawati ${ }^{*}$, Aas Nur Fajriah ${ }^{1}$, Nur Sekar Ramadhina ${ }^{1}$, Echa Rahayu ${ }^{1}$, \\ Tiffeny Nuaidah ${ }^{1}$, Yohana Puspitasari ${ }^{1}$
}

1Program Studi Pendidikan Biologi, Universitas Wiralodra, Jl. Ir. H. Juanda Km 3 Indramayu, Indonesia, 45218

*Email koresponden: lesy.luzyawati@unwir.ac.id

\author{
ARTICLE INFO \\ Article history \\ Received: 04 Feb 2021 \\ Accepted: 06 Nov 2021 \\ Published: 31 Des 2021
}

\section{Kata kunci: \\ Ikan Tongkol; \\ Kaldu udang; \\ Kulit Udang; \\ Pemberdayaan; \\ Penyedap Makanan; \\ Sosis Ikan;}

\begin{abstract}
A B S T R A K
Background: Potensi sumber daya alam yang besar tersebut tidak diimbangi dengan pemanfaatan yang optimal oleh masyarakat setempat yang ditandai dengan rendahnya nilai jual produk perikanan olahan nonekonomis. Hal ini dikarenakan adanya kesamaan pengetahuan masyarakat setempat dalam meningkatkan nilai jual produk perikanan. Selain itu, tingginya jumlah limbah udang menjadi permasalahan yang perlu dicari pemanfaatannya yang memiliki nilai jual. Metode: Oleh karena itu, perlu dilakukan penyuluhan kepada masyarakat Desa Karangsong mengenai pentingnya pemanfaatan ikan tuna dalam sosis ikan dan pengolahan kepala, kulit, dan ekor udang sebagai bahan penyedap makanan untuk meningkatkan nilai ekonomi. Metode yang digunakan adalah edukasi masyarakat berupa sosialisasi ikan tuna dan kulit serta kepala udang. Hasil: Sosialisasi pemanfaatan ikan tuna serta kulit dan kepala udang yang diolah menjadi pengolahan makanan dan penyedap rasa. Sosialisasi ini dilakukan di Desa Karangsong, Kecamatan Indramayu, Kabupaten Indramayu. Kesimpulan: Berdasarkan pelaksanaan kegiatan pengabdian kepada masyarakat yang telah dilakukan dapat disimpulkan bahwa masyarakat memahami bagaimana memanfaatkan hasil non ekonomi agar memiliki nilai ekonomi dan masyarakat dapat memahami bahwa pengelolaan sampah telah menjadi produk yang bernilai ekonomi. A B S T R A C T

Background: The large potential of natural resources is not matched by optimal utilization by local communities marked by the low selling value of non-economic processed fishery products. This is due to the local community's common knowledge in increasing the selling value of fishery products. Method: Besides, the high amount of shrimp waste is a problem that needs to be searched for its use of which has a sale value. Therefore, it is necessary to deliver education to Karangsong Village's community regarding the importance of using tuna fish in fish sausages and processing the head, skin, and tail of shrimp as a food flavoring ingredient to increase economic value. The method used is community education in the form of socialization of tuna fish and shrimp skin and head. Result: The socialization of tuna fish utilization and the skin and head of shrimp are processed into food processing and flavorings. This socialization was conducted in Karangsong Village, Indramayu District, Indramayu Regency. Conclusion: Based on the implementation of community service activities that have been carried out, it can be concluded that the community understands how to use non-economic results to have economic value and the community can understand that waste management has become a product of economic value.
\end{abstract}




\section{PENDAHULUAN}

Desa Karangsong adalah salah satu desa di Kecamatan Indramayu, Kabupaten Indramayu yang berada di pesisir pantai. Wilayah ini berupa daratan pesisir dengan potensi sumber daya perikanan yang cukup besar seperti mangrove, ikan, dan rumput laut. Besarnya potensi sumber daya alam ini tidak diimbangi dengan pemanfaatan yang optimal oleh masyarakat lokal yang ditandai dengan rendahnya nilai jual produk olahan perikanan non ekonomi. Kondisi demikian disebabkan rendahnya pengetahuan masyarakat lokal dalam meningkatkan nilai jual dari produk perikanan sehingga perikanan yang dihasilkan hanya dijual dalam bentuk segar.

Ikan-ikan yang sudah memiliki nilai ekonomi tinggi dan mudah dimanfaatkan tidak sulit untuk dijual. Misalnya ikan kerapu, kakap, etong yang banyak dicari terutama oleh resto atau warung makan karena ikan tersebut biasa dijual dalam bentuk ikan bakar/goreng. Namun, ikanikan yang perlu pengolahan ekstra kurang diminati pasar sehingga butuh pengolahan lebih lanjut agar mempunyai nilai jual. Salah satunya ikan tongkol yang memiliki karakteristik dapat menyebabkan alergi karena adanya protein alergen (Chalid et al., 2019). Padahal ikan tongkol memiliki gizi yang cukup tinggi. Setiap 100 gram mempunyai komposisi kimia yang tediri dari air 69,40\%, lemak 1,50\%, protein 25,00\% dan karbohidrat 0,03\% (Sanger, 2010), serta mengandung beberapa mineral seperti kalsium, fosfor, besi, sodium, vitamin A (retinol), dan vitamin B (thiamin, riboflavin dan niasin) (Hafiludin, 2011). Kandungan gizi yang banyak serta adanya protein penyebab alergi pada ikan tongkol membuat perlunya pengolahan lebih lanjut terhadap ikan tongkol.

Selama ini ikan tongkol banyak diolah dengan cara di buat pindang. Ikan tongkol yang di pindang dengan cara oven steam selama 3 jam banyak disukai masyarakat (Hidayat, et al., 2020). Pengolahan ikan tongkol lainnya yaitu ikan tongkol asap (Junianingsih, 2013), ikan tongkol presto, dan risoles tongkol (Diniarti et al., 2020). Ikan tongkol memiliki kadar asam amino histidin tinggi sehingga pengolahannya baik jika dikukus (Supraptini et al., 1999). Salah satu olahan yang dilakukan dengan mengukus yaitu pembuatan sosis ikan tongkol. Edukasi terhadap masyarakat Desa Karangsong Indramayu bertujuan agar dapat mengolah ikan tongkol menjadi sosis, sehingga dapat meningkatkan nilai ekonomi.

Berbeda dengan hasil perikanan yang sudah memiliki nilai ekonomi tinggi, misalnya udang. Udang pada umumnya dimanfaatkan sebagai bahan makanan yang memiliki nilai gizi tinggi. Bagian yang dikonsumsi hanyalah daging, sedangkan kepala, kulit, dan ekor dibuang begitu saja sehingga menimbulkan permasalahan limbah. Limbah udang ini kemudian menjadi sampah yang pemanfaatan kurang maksimal sehingga menyebabkan pencemaran lingkungan khususnya bau dan estetika lingkungan yang buruk (Mustafiah, et al., 2018). Aroma yang tidak sedap menyebabkan hewan-hewan pembawa bibit penyakit berkumpul dan berkembangbiak (Atika \& Handayani, 2019).

Jumlah limbah udang yang tinggi merupakan masalah yang perlu di carikan upaya pemanfaatannya, untuk memberikan nilai tambah pada usaha pengolahan udang, serta dapat menanggulangi masalah pencemaran yang ditimbulkan (Swastawati et al., 2008). Sudah sejak lama peneliti mengembangkan penelitian-penelitian yang menjadikan limbah hasil perikanan sebagai bahan dasar penelitian, seperti cangkang udang menjadi nanokitosan (Suptijah, Jacoeb, \& Rahmania, 2011).

Upaya pemanfaatan limbah udang yaitu dapat dijadikan sebagai kaldu penyedap masakan. Kaldu bubuk berbahan dasar limbah udang ini mengandung nilai gizi yang tinggi dan juga tanpa bahan pengawet. Selain dapat digunakan sebagai penambah cita rasa, kepala, kulit dan ekor udang juga mempunyai manfaat melawan radikal bebas sepuluh kali lebih baik dari pada buah dan sayur karena mengandung antioksidan astaxanthin (Detikhealth, 2013) dan mengatasi mata 
lelah karena adanya zat astaxanthin, memiliki kandungan glucosamine untuk membantu pembentukan tulang rawan dan masalah persendian. Kandungan kalsium dan fosfor yang kaya pada kulit udang dapat membantu pertumbuhan tulang dan gigi.

Selain itu, Limbah udang juga mengandung protein kasar sekitar 25-40\%, kalsium karbonat 45-50\% dan kitin 15-20\% (Wowor et al., 2015). Selain sebagai sumber yang telah disebutkan, limbah udang sendiri mengandung karotinoid berupa astaxantin yang merupakan pro vitamin A untuk pembentukan warna kulit.

Tujuan kegiatan pengabdian masyarakat ini adalah mengedukasi masyarakat di Desa Karangsong pentingnya memberikan informasi cara pemanfaatan ikan tongkol menjadi sosis ikan dan mengolah kepala, kulit, ekor udang sebagai bahan penyedap masakan untuk meningkatkan nilai ekonomi.

\section{MASALAH}

Potensi sumber daya alam masyarakat Desa Karangsong cukup melimpah terutama hasil laut, namun yang menjadi kendala yaitu pemanfaatan sumber daya tersebut kurang optimal. Hal ini disebabkan rendahnya pengetahuan masyarakat lokal dalam meningkatkan nilai jual dari produk perikanan. Produk perikanan yang dihasilkan hanya dijual dalam bentuk segar. Sehingga nilai jual produk olahan laut non ekonomi rendah. Masalah lain muncul untuk produk olahan perikanan yang memiliki nilai tinggi seperti udang yang hanya dimanfaatkan dagingnya saja menimbulkan limbah berupa kulit udang dan kepala udang. Berdasarkan hal tersebut perlu adanya edukasi masyarakat Desa Karangsong mengenai cara pemanfaatan ikan tongkol menjadi sosis ikan dan mengolah kepala, kulit, ekor udang sebagai bahan penyedap masakan untuk meningkatkan nilai ekonomi.

\section{METODE PELAKSANAAN}

Metode yang dilakukan adalah pendidikan masyarakat berupa sosialisasi pemanfaatan ikan tongkol dan kulit serta kepala udang. Sosialisasi pemanfaatan ikan tongkol dan kulit serta kepala udang diolah menjadi olahan makanan dan penyedap rasa. Sosialisasi ini dilakukan di Desa Karangsong Kecamatan Indramayu Kabupaten Indramayu. 10 Juni 2020 sampai dengan 10 Agustus 2020. Kegiatan ini dilakukan selama 2 bulan.

Adapun tahapan-tahapan yang dilaksanakan meliputi, diantaranya:

a. Persiapan

Kegiatan persiapan dilakukan melalui tiga tahapan, yaitu: seleksi lokasi dan analisis permasalahan. Seleksi lokasi dilakukan untuk menentukan tempat atau wilayah pelaksanaan pemberdayaan masyarakat yang diinginkan. Pemilihan lokasi disesuaikan dengan masalah potensi yang ditemukan di suatu wilayah untuk mencari alternatif pemecahan masalah, masyarakat bersedia menerima kegiatan non-fisik, tidak terlalu banyak kegiatan keproyekan lain, serta lokasi terjangkau, sesuai kemampuan dan sarana. Berdasarkan hal tersebut maka Desa Karangsong dipilih sebagai lokasi pelaksanaan sesuai dengan permasalahan yang ada.

b. Sosialisasi dan pengenalan produk

Sosialisasi dan pengenalan produk dilakukan dengar apa tahapan yaitu 1) survey kelompok sasaran, kegiatan ini dilakukan dengan menyebarkan angket dan melakukan wawancara. 2) sarana dan prasarana, 3) pelaksanaan kegiatan inti, adapun pelaksanaan kegiatan inti dilakukan dengan membentuk kelompok kecil yang sesuai dengan protokol kesehatan gugus tugas COVID-19. Hal ini dilakukan karena masih terjadi pandemik COVID-19. Sosialisasi dilakukan untuk menciptakan komunikasi serta dialog dengan masyarakat untuk meningkatkan pengertian masyarakat tentang produk yang akan diperkenalkan, dan 4). 
Evaluasi, dilakukan dengan uji organoleptik yaitu menyebarkan angket. Tahapan dan metode dalam proses sosialisasi meliputi: pemaparan produk dengan jumlah peserta 10 orang dengan dibagi menjadi 2 kelompok kecil.

\section{HASIL DAN PEMBAHASAN}

\section{Persiapan}

Kegiatan pengabdian kepada masyarakat (PKM) ini dilakukan pada tanggal 10 Juni sampai dengan 10 Agustus 2020. Tahap awal pada kegiatan PKM ini dilakukan tahap seleksi lokasi. Seleksi lokasi ini dilakukan untuk mendapatkan lokasi yang sesuai dan terdekat dengan Universitas. Hal ini dilakukan agar kampus memiliki manfaat untuk lingkungan sekitar. Melalui tahap seleksi lokasi ini dipilihlah Desa Karangsong Kecamatan Indramayu kabupaten Indramayu sebagai tempat pemberdayaan masyarakat dilaksanakan. Desa Karangsong merupakan desa pantai. Sebagai desa pantai, Karangsong memiliki kontur wilayah berupa daratan landai dengan substrat lumpur berpasir sampai tanah padat, dan wilayah laut. Desa Karangsong memiliki penduduk sebanyak 6.740 jiwa dengan 2.117 jumlah total Kepala Keluarga (KK), terdiri 3.452 orang laki-laki dan 3.288 orang perempuan. Dimana pada Desa Karangsong terdapat Tempat Pelelangan Ikan (TPI). Selain itu menurut Adibowo (2014), kondisi masyarakat pesisir atau masyarakat nelayan pada umumnya ditandai oleh adanya beberapa ciri, seperti kemiskinan, keterbelakangan sosial-budaya, rendahnya sumber daya manusia (SDM), dan lemahnya fungsi dari keberadaan Kelompok Usaha Bersama (KUB), atau kapasitas berorganisasi masyarakat.

Masyarakat Desa Karangsong sebagian besar berprofesi sebagai nelayan, dimana para nelayan ini mengandalkan hasil laut sebagai pendapatan utamanya. Namun, tidak semua hasil laut memiliki nilai ekonomi yang tinggi. Selain permasalahan tersebut, juga didapatkan permasalahan pengolahan udang hasil laut yang hanya dimanfaatkan dagingnya saja. Sehingga lama kelamaan jika limbah kulit udang dibiarkan begitu saja akan menumpuk dan menimbulkan bau tidak sedap. Oleh karena itu, kami memanfaatkan ikan non-ekonomi dan limbah kulit udang untuk diolah menjadi olahan makanan yang bernilai ekonomi. Olahan tersebut menjadi sosis ikan dan kaldu kulit udang. Adapun data peserta sosialisasi yang hadir tersedia pada Tabel 1.

Tabel 1. Data Peserta Sosialisasi

\begin{tabular}{llc}
\hline \multicolumn{1}{c}{ Nama } & \multicolumn{1}{c}{ Alamat } & Usia \\
\hline Sarini & Karangsong & 34 \\
Iis & Karangsong & 25 \\
Sunenti & Karangsong & 45 \\
Kartinisss & Karangsong & 55 \\
Narti & Karangsong & 37 \\
Tati & Karangsong & 45 \\
Ibek & Karangsong & 25 \\
Taufik Suhada & Karangsong & 40 \\
Jaenal Arifin & Karangsong & 41 \\
Jumaeriyah & Karangsong & 45 \\
Karmi & Karangsong & 59 \\
Halimah & Karangsong & 39 \\
\hline
\end{tabular}

Penduduk dengan usia produktif (15 - 60 tahun) dan berprofesi sebagai nelayan memiliki persentase yang cukup besar. Kondisi penduduk tersebut merupakan kekuatan yang dimiliki oleh Desa Karangsong dalam mengembangkan potensi sumber perairan melalui kegiatan ini. Kelompok sasaran kegiatan ini adalah kaum perempuan dengan jumlah 3 orang. 


\section{Sosialisasi Pemberdayaan Masyarakat}

Sosialisasi program dilaksanakan pada Rabu, 19 Mei 2020. Kegiatan sosialisasi dilakukan untuk menciptakan komunikasi serta dialog dengan masyarakat untuk meningkatkan pemahaman kepada masyarakat tentang program yang akan dilaksanakan. Kegiatan sosialisasi ini memberikan hasil yang baik, masyarakat Desa Karangsong. Dukungan penuh dari pihak masyarakat terlihat dari peran mereka selama mengikuti kegiatan sosialisasi penyediaan tempat untuk pelaksanaan kegiatan (rumah warga) seperti yang terlihat pada Gambar 1.
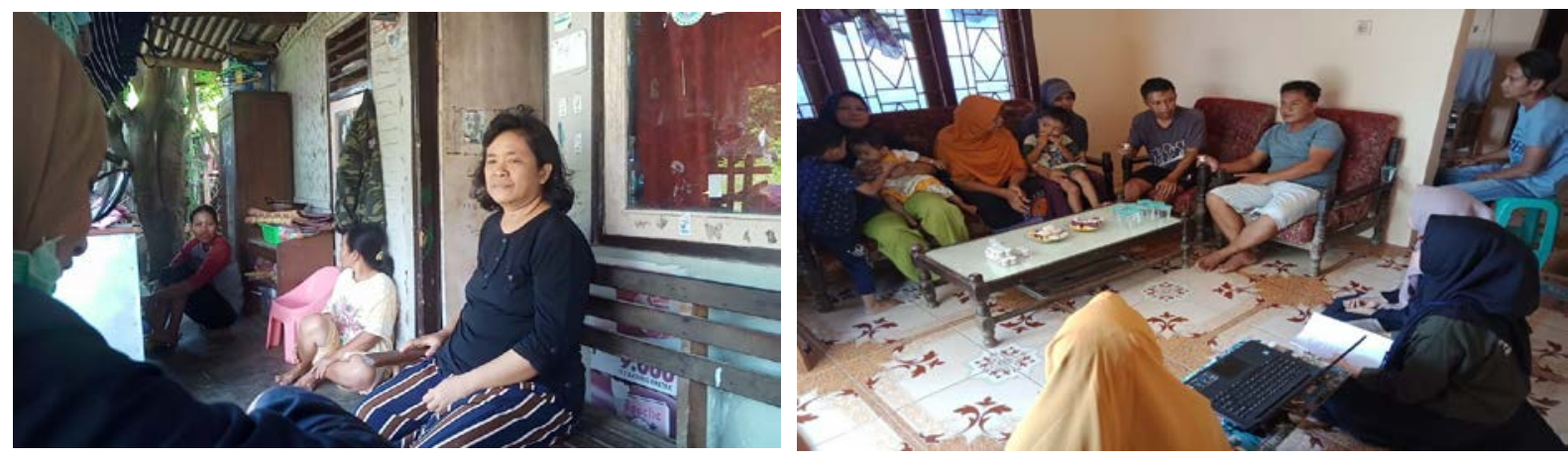

Gambar 1. Pelaksanaan Sosialisasi di masyarakat Desa Karangsong

\section{Hasil Angket Uji Organoleptik}

\section{Sosis Ikan Non-Ekonomi}

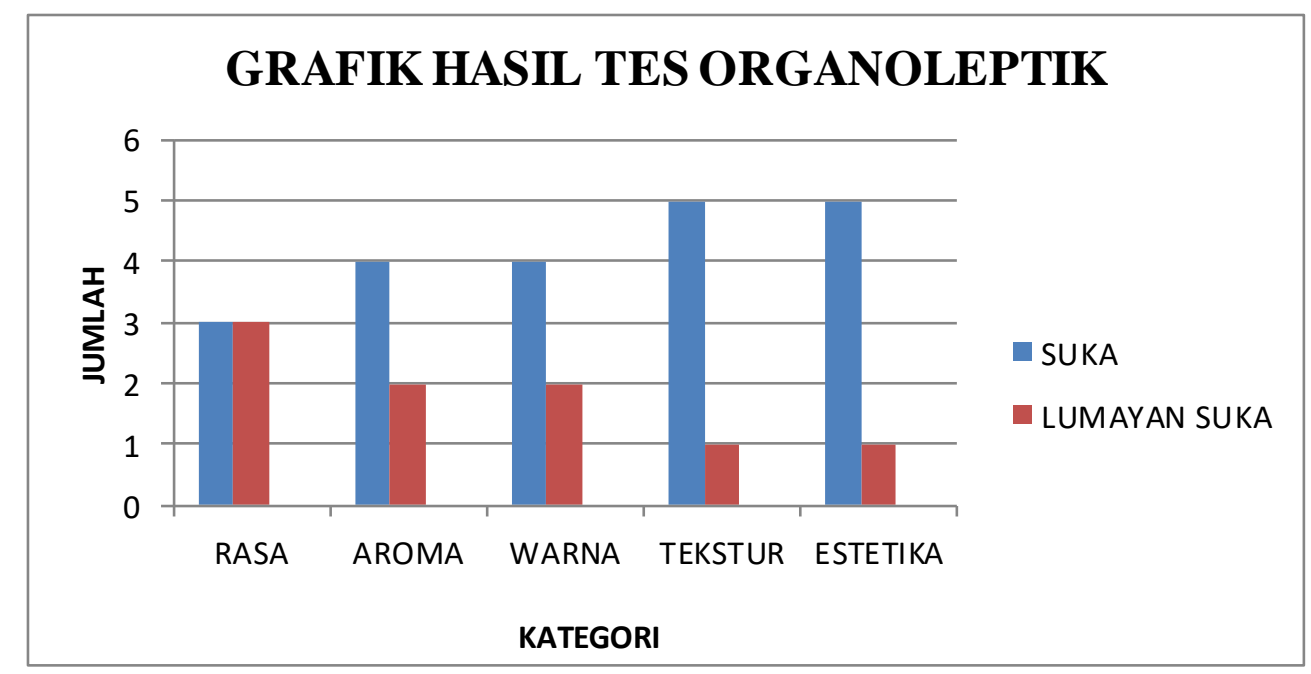

Gambar 2. Grafik Hasil tes Orgamoleptik

Gambar grafik tersebut menjelaskan bahwa dari 6 peserta yang menyukai rasa dari sosis ikan ada 3 peseta dan sisanya lumayan menyukainya. Dari 6 peserta yang menyukai aromanya ada 4 peserta dan sisanya lumayan suka. Dari segi warna ada 4 peserta yang suka dengan warnanya dan sisanya lumayan suka. Dari segi tekstur ada 5 peserta yang suka dengan teksturnya dan sisanya lumayan suka. Terakhir dari segi estika ada 5 orang yang suka dengan teksturnya dan sisanya lumayan suka. 


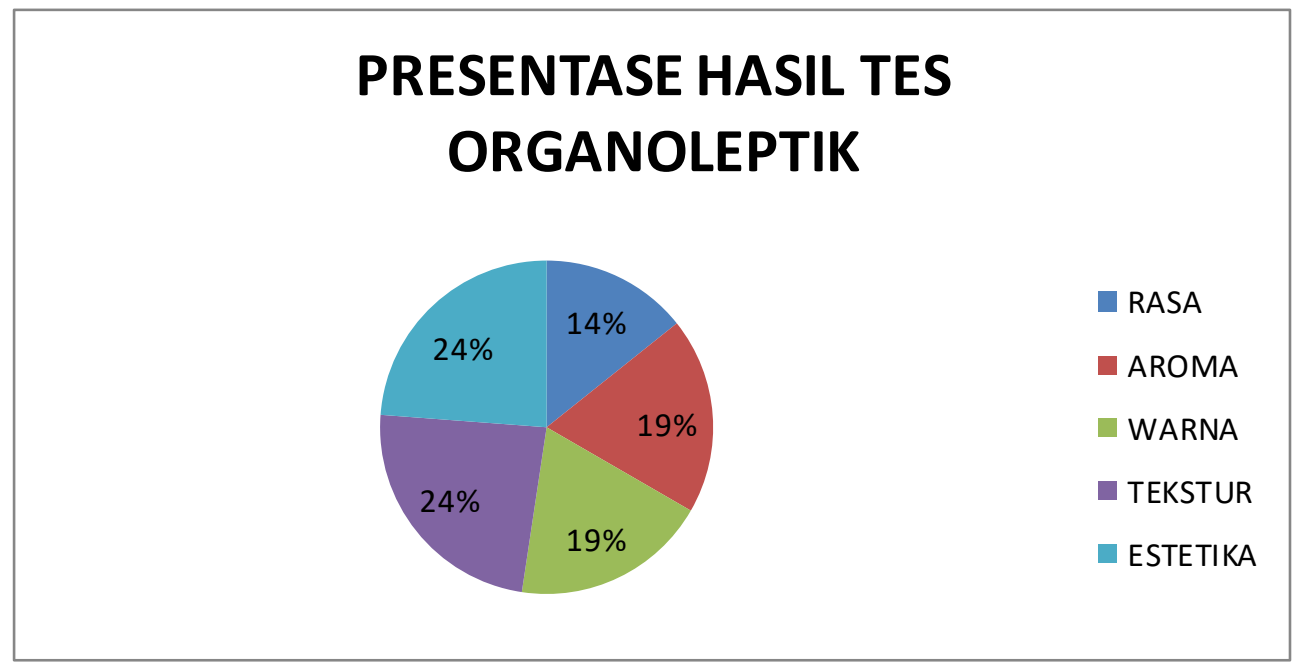

Gambar 3. Presentase Hasil Tes Organoleptik

\section{Kaldu Kulit Udang}

Udang merupakan biota laut yang tergolong kelas decapoda, karena decapoda tubuh udang dibagi menjadi tiga bagian yaitu kepala, dada dan perut. Bagian tubuh udang yang terbagi menjadi tiga bagian sehingga udang sering diproduksi pada pabrik-pabrik hanya bagian dada dan perut, bagian kepala termasuk limbah pabrik yang masih minim pemanfaatannya (Meiyani et al, 2014).

Potensi limbah industri berupa kepala udang yang cukup besar yakni dapat mencapai 3649\% untuk bagian kepala dari keseluruhan berat badan kepala udang memiliki komposisi asam amino salah satunya asam glutamat $\pm 20,45 \mathrm{mg}$ untuk memenuhi kebutuhan protein harian.

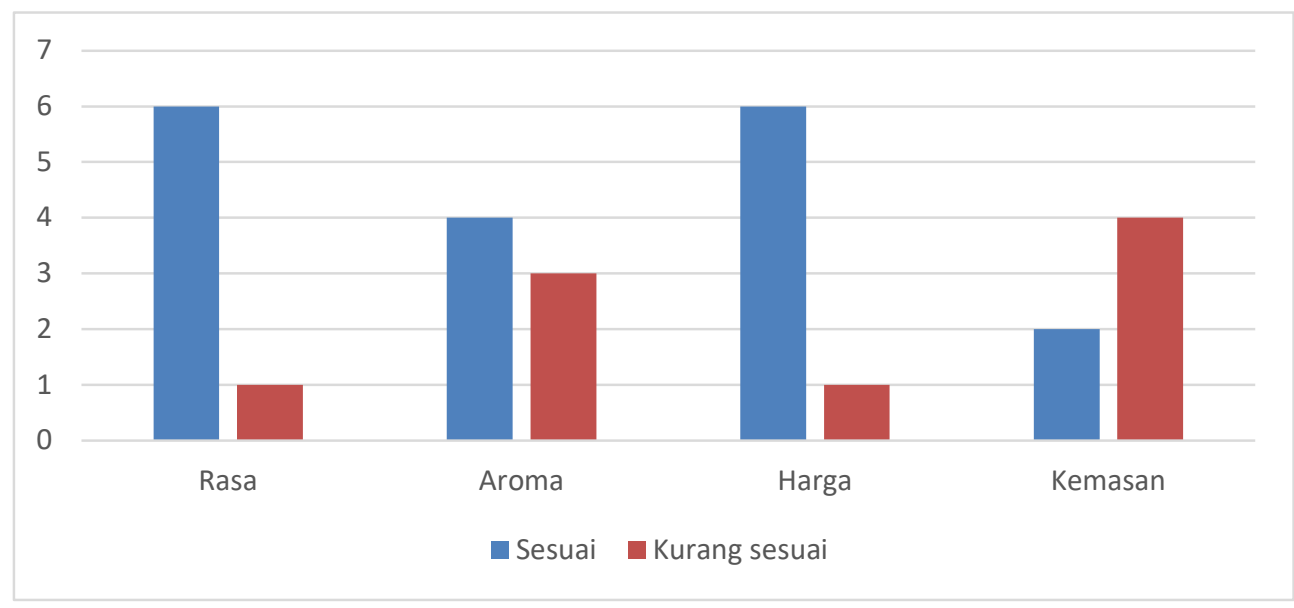

Gambar 4. Grafik Tanggapan Masyarakat Terhadap Produk

Dilihat dari hasil kuesioner yang diisi oleh masyarakat yang mengikuti kegiatan sosialisasi tersebut, di dapatkan hasil bahwa dari segi rasa sudah bagus, karena memiliki dua varian rasa yang berbeda yaitu original dan pedas. Sedangkan dari segi kemasan, sebagian masyarakat menyarankan untuk menggunakan kemasan plastik seperti kemasan royco/masako, karena agar terlihat seperti penyedap masakan pada umumnya. Dari harga yang di paparkan sudah termasuk pas seperti harga penyedap masakan pada umumnya yaitu Rp. 3.000.

\section{Capaian Kegiatan PKM}


Capaian kegiatan PKM dilihat dari tiga indikator yaitu pemahaman masyarakat, keterampilan masyarakat, dan kemampuan berwirausaha masyarakat: 1) Pemahaman masyarakat mengenai metode pengolahan. Produk perikanan yang dihasilkan oleh masyarakat Desa Karangsong selama ini hanya dijual dalam bentuk segar, sehingga produk yang dihasilkan tidak bertahan lama dan mudah rusak. Selain itu. kulit udang biasanya hanya dibuang begitu saja tanpa diolah; 2) Kegiatan pemberdayaan yang dilaksanakan mampu meningkatkan keterampilan masyarakat dalam meningkatkan nilai jual produk perikanan dan limbah kulit udang tersebut; dan 3) Peningkatan kemampuan masyarakat dalam berwirausaha dengan berhasilnya membuat dan memasarkan produk olahan.

\section{Kesulitan dan Keberlanjutan Kegiatan}

Kendala dan Keberlanjutan Kegiatan pengabdian masyarakat ini diharapkan dapat berlangsung secara berkelanjutan. Program ini diharapkan tidak sekedar menjadi program atau proyek semata, tetapi betul-betul dapat diimplementasikan oleh masyarakat Desa Karangsong. Pada akhirnya pelaksanaan sosialisasi yang diberikan kepada masyarakat dapat digunakan untuk menyokong perekonomian dalam rumah tangga mereka dan untuk menjawab persoalan yang selama ini mereka hadapi, sehingga secara ekonomi mereka dapat mandiri tanpa mengandalkan dana bantuan dari pemerintah. Masyarakat mulai mengaplikasikan hasil dari sosialisasi ini dengan memproduksi kaldu dari limbah kepala udang dan sosis ikan untuk dijual kepada ibu-ibu rumah tangga dan jajanan anak-anak. Agar kegiatan ini dapat berlangsung secara berkelanjutan, maka pelibatan anggota masyarakat sebagai kunci utama dalam meneruskan kegiatan program tetap dilaksanakan.

\section{KESIMPULAN}

Kegiatan pengabdian kepada masyarakat yang bersifat penyuluhan atau sosialisai tentang menaikkan nilai ekonomi produk olahan perikanan non ekonomi, serta pemanfaatan limbah udang sebagai produk olahan bumbu atau kaldu memberikan pemahaman kepada masyarakat untuk menerapkan hal tersebut. Kegiatan ini merupakan kegiatan untuk menyampaikan pengetahuan kepada masyrakat tentang menaikkan nilai ekonomi produk olahan perikanan non ekonomi, serta pemanfaatan limbah udang sebagai produk olahan bumbu atau kaldu. Saran untuk kegiatan berikutnya yaitu perlu dilakukan sosialisasi lebih luas untuk menaikkann nilai ekonomi produk perikanan yang non ekonomi.

\section{UCAPAN TERIMA KASIH}

Ucapan terima kasih kepada Lembaga Penelitian dan Penabdian Kepada Masyarakat (LPPM) Universitas Wiralodra, Pemerintah Desa Karangsong, dan Masyarakat Desa Karangsong, serta semua pihak yang telah membantu pelaksanaan pengabdian masyarakat ini.

\section{DAFTAR PUSTAKA}

Adibowo, R. (2014). Implementasi Kebijakan Pemberdayaan Ekonomi Masyarakat Pesisir (Studi di Desa Karangsong Kabupaten Indramayu Provinsi Jawa Barat). Jurnal Ilmu Politik dan Komunikasi, 4(2), 115126.

Atika, S. \& Handayani, L. (2019). Pembuatan Bubuk Flavour Kepala Udang Vannamei (Litopenaus Vannamei) Sebagai Pengganti Msg (Monosodium Glutamat). Prosiding Semdi Unaya, 3(1), 18-26. 
Chalid, S. Y., Syah, D., Giriwono, P. E., Rungkat, F., \& Zakaria. (2019). Profille and Sensitivity of Protein Alergens of Tuna Fish As a Skin Prick Test (Spt) Reagent. Jurnal Kimia Valensi, 5(1), 44-45.

Detikhealth. (2013). Dianggap Sisa dan Selalu Terbuang, Padahal Banyak Manfaat Sehatnya. [Online]. [Diakses 25 Agustus 2020]. Tersedia Pada: Https://Health.Detik.Com/Hidup-Sehat-Detikhealth/D2275792/Dianggap-Sisa-Dan-Selalu-Terbuang-Padahal-Banyak-Manfaat-Sehatnya.

Diniarti, N., Cokrowati, N., Setyowati, D. N. Mukhlis, A. (2020). Edukasi Nilai Gizi Ikan Melalui Pelatihan Pembuatan Makanan Olahan Berbahan Baku Ikan Tongkol. Jurnal Abdi Insani, 7(1), 49-54.

Hafiludin. (2011). Karakteristik Prosimat dan Kandungan Senyawa Kimia Daging Putih dan Daging Merah Ikan Tongkol (Euthynnus Affinis). Jurnal Kelautan, 4(1), 1-10.

Hidayat, R., Maimun., Sukarno. (2020). Analisis Mutu Pindang Ikan Tongkol (Euthynnus Affinis) dengan Teknik Pengolahan Oven Steam. Jurnal Fishtech, 9(1), 21-33.

Junianingsih, I. (2013). Analisis Profitabilitas Usaha Pengolahan Tradisional Ikan Tongkol Asap di Desa Jangkar Kabupaten Situbondo. Samakia: Jurnal Ilmu Perikanan, 4(2), 86-93.

Meiyani et al. (2014). Pemanfaatan Air Rebusan Kepala Udang Putih (Paneus Merguensis) Sebagai Flavor dalam Bentuk Bubuk dengan Penambahan Maltodekstrin. Jurnal Pengolahan dan Bioteknolgi Hasil Perikanan, 3(2), 67-68.

Mustafiah, M. Darnengsih, D., Sabara, Z., \& Majid, R. A. (2018). Pemanfaatan Kitosan Dari Limbah Kulit Udang Sebagai Koagulan Penjernihan Air. Journal Of Chemical Process Engineering, 3(1), 27-32.

Sanger, G. (2010). Oksidasi Lemak Ikan Tongkol (Auxfs Thazard) Asap yang Direndam dalam Larutan Ekstrak Daun Sirih. Pacific Journal, 2(5), 870-8733.

Supraptini, Minah, N. S, Estari, E. W, Olan, R. A., Jarismawati, \& Ugihar. (1999). Penelitian Tentang Cara Pengolahan Ikan Laut (Tongkol Dan Kembung) yang Aman Untuk Kesehatan. Buletin Penelitian Kesehatan 26(2\&3). 109-118.

Suptijah, P., Jacoeb, A. M., \& Rahmania, D. (2011). Karakterisasi Nanokitosan Cangkang Udang Vannamei (Litopenaus Vannamei) Dengan Metode Gelasi Ionik. Jurnal Pengolahan Hasil Perikanan Indonesia, 14(2), 78-84.

Swastawati, F., Wijayanti, I., \& Susanto, E. (2008). Pemanfaatan Limbah Kulit Udang Menjadi Edible Coating untuk Mengurangi Pencemaran Lingkungan. Jurnal Teknologi Lingkungan, 4(4), 101-106

Wowor, A. R. Y., Bagau, B., Untu, I.,\& Liwe, H. (2015). Kandungan Protein Kasar, Kalsium, dan Fosfor Tepung Limbah Udang sebagai Bahan Pakan yang Diolah dengan Asam Asetat $\left(\mathrm{CH}_{3} \mathrm{COOH}\right)$. Jurnal Zootek, 35(1), 1-9 